\title{
Positioning Digital Tracing Applications in the Management of the COVID-19 Pandemic in France
}

Marion Albouy-Llaty ${ }^{1,2,3}, \mathrm{MD}, \mathrm{PhD}$; Caroline Martin ${ }^{4,5}$; Daniel Benamouzig ${ }^{6,7}, \mathrm{PhD}$; Eric Bothorel ${ }^{8}$; Gilles Munier ${ }^{9}$, MD; Catherine Simonin ${ }^{10}$; Jean-Louis Guéant ${ }^{11,12}$, MD, PhD; Emmanuel Rusch ${ }^{13,14}$, MD, PhD

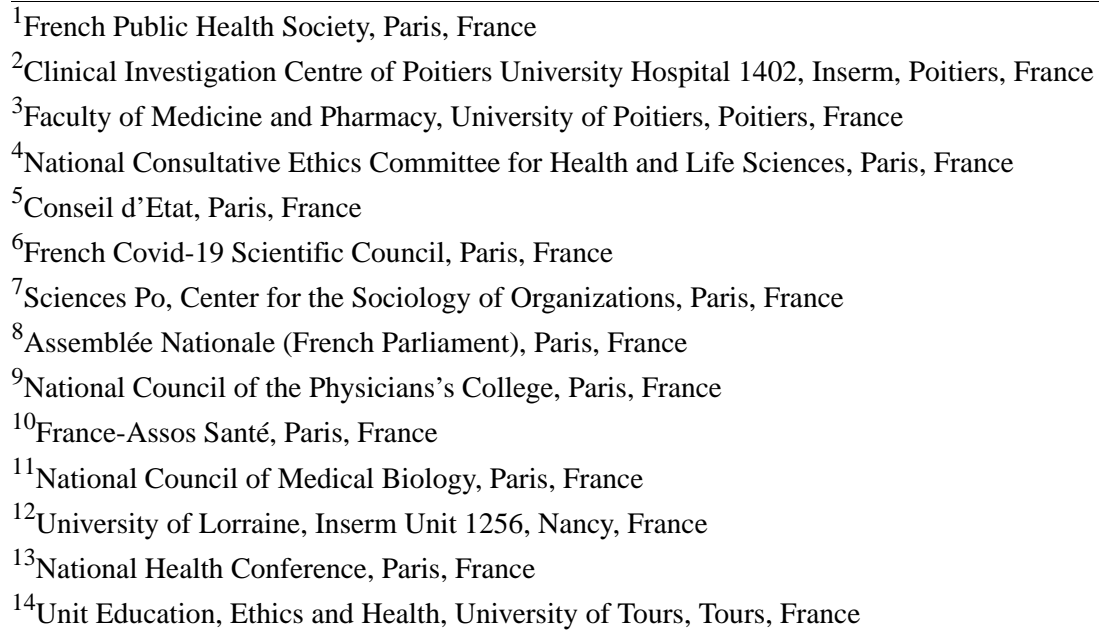

\section{Corresponding Author:}

Marion Albouy-Llaty, MD, PhD

Faculty of Medicine and Pharmacy

University of Poitiers

6 rue de la Milétrie

Poitiers, 86021

France

Phone: 330669660192

Email: marion.albouy@univ-poitiers.fr

\section{Abstract}

To combat the COVID-19 pandemic, many European countries have developed a public health strategy involving the use of digital contact tracing (DCT) applications to improve timely tracking and contact tracing of COVID-19 cases. France's independent COVID-19 Control and Society Connection Council (CCL) was established by law in May 2020 to issue advice and recommendations on the national epidemic digital systems. In this paper, we present the recommendations by the CCL, with the objective to increase the uptake and utility of French DCT applications. As the country's most vulnerable population has been subjected to greater virus exposure, a stronger impact of the lockdown, and less access to preventive and health care services, the CCL is particularly aware of health inequalities. The French DCT app TousAntiCovid had been downloaded by 13.6 million users (ie, 20\% of the French population) in March 2021. To promote the use of DCT apps, the CCL has recommended that communication about the app's individual and collective objectives be increased. The CCL has also recommended the introduction of clear, simple, accessible, incentivizing, noncoercive information within the digital tools. In addition, the CCL has recommended improving public health policies to address the needs of the underprivileged. The CCL calls for promoting population empowerment with the use of digital tools, improving public health culture for decision-makers dealing with health determinants, taking social considerations into account, and incorporating community participation.

(J Med Internet Res 2021;23(10):e27301) doi: 10.2196/27301

\section{KEYWORDS}

COVID-19 pandemic; digital contact tracing applications; health inequalities; Europe; health promotion 


\section{Introduction}

To combat the first wave of the COVID-19 pandemic, many European countries instituted a strict lockdown coupled with reverse-transcription polymerase chain reaction (RT-PCR) testing, which led to a relative decline in case fatality [1]. These countries also developed a public health strategy involving the use of digital contact tracing (DCT) applications to improve timely tracking and contact tracing [2,3]. Despite these measures, the second epidemic wave occurred in autumn 2020, more rapidly and with a higher severity than expected, leading to a second lockdown in many countries. France developed a national "Test, Trace and Isolate" strategy, but did not achieve its goal of less than 5000 confirmed COVID-19 cases per day by December 15, 2020. As of that date, incidence had increased, and a curfew went into effect first. Several weeks later, in facing a third wave, a lockdown was reinstituted by many countries.

\section{Recommendations for DCT Use in France}

France's independent COVID-19 Control and Society Connection Council (CCL) was established by law in May 2020 in order to issue advice and recommendations on the national epidemic digital systems. The CCL comprises 13 members, including representatives from the parliament and civil society, patient organizations, jurists, and academics from different disciplines (see Multimedia Appendix 1 [4]). Considering the characteristics of European DCT apps and their potential, we present the CCL's recommendations, with the objective to increase the uptake and utility of French DCT apps. As the country's most vulnerable population has been subjected to greater virus exposure, a stronger impact of the lockdown, and less access to preventive and health care services, the CCL is particularly aware of prevailing health inequalities.

\section{Findings}

Several mobile apps for contact tracing and information on public health policy have been developed in Europe (Table 1). These apps should respond to scientifically valid and time-bound ethical guidelines. Insufficient privacy protection could erode trust in the government and public health services [5,6]. Unfortunately, adoption of these apps has been below expectations [7]; although, adoption has been high in Finland (45\%), it has been limited elsewhere (24\% in Ireland, $21 \%$ in Switzerland, $19 \%$ in Germany, and 13\% in Italy [8]; see Table 1). The French DCT StopCovid app was based on
Bluetooth-based exposure notification. Conceived as a silent app (ie, without interactivity), it was replaced on October 22, 2020, by a conversational app renamed TousAntiCovid. Among 66 million inhabitants, only 1.5 million (2.3\%) had downloaded the StopCovid app and, as of March 2021, this number increased to 13.6 million (ie, $20 \%$ of the French population). Moreover, positive test declarations $(n=183,377)$, such as notifications of a contact $(n=107,465)$ have been weak. The poor results of the StopCovid app stemmed from the lack of attractiveness and prevention information, a fear of insufficient privacy protection, Bluetooth connection problems, and the incompatibility of apps with older smartphones.

To promote the use of the apps, the CCL recommended increasing the communication about the individual and collective objectives of the TousAntiCovid app. The CCL also recommended the introduction of clear, simple, accessible, incentivizing, noncoercive information in the digital tool. Indeed, the messages aimed at emphasizing risk are less effective than those encouraging self- and collective efficacy [9]. Moreover, to stimulate DCT uptake, apps should enhance perceived benefits [10]. In addition, the CCL recommended improving public health policies to address the needs of the underprivileged population [11]. It bears mentioning that apps are effective only if users are comfortable with digital tools; technical problems are among the main reasons for failure to download [12]. It is also worth noting that the COVID-19 pandemic has accelerated digital health uptake: $49 \%$ of the French population used their first health digital tool during the first lockdown [13], whereas $16 \%$ of French population never connect to internet [14].

The CCL believes that the national "Test, Trace and Isolate" strategy needed consistency-testing without effective tracing and efficient isolation of positive cases makes little, if any, sense. In Europe and France, apps have progressively incorporated an isolation module (questions about needs during isolation). Their development should be aimed at measuring isolation prescription and adherence. Apps could help families to stay connected and maintain links to resources that support their physical and mental well-being [15]. Despite contrasting strategies of lockdown, no dramatic difference in the magnitude of the second epidemic wave seems to have been observed among these countries (Table 1). For persons with positive test results, the strategy adopted in most countries included a mandatory 7-day isolation until newer variants of SARS-CoV-2 were discovered [16]. 
Table 1. European data on COVID-19 mortality, government stringency responses, and digital contact tracing (DCT) applications as of December 15, 2020 .

\begin{tabular}{|c|c|c|c|c|c|c|c|c|}
\hline $\begin{array}{l}\text { European } \\
\text { country }\end{array}$ & Population & $\begin{array}{l}\text { Unstandardized } \\
\text { COVID-19 mor- } \\
\text { tality (per million } \\
\text { inhabitants) }\end{array}$ & $\begin{array}{l}\text { Government re- } \\
\text { sponse stringen- } \\
\text { cy index }{ }^{\mathrm{a}}[17]\end{array}$ & DCT app name & $\begin{array}{l}\text { Data destruc- } \\
\text { tion apps da- } \\
\mathrm{ta}^{\mathrm{b}}\end{array}$ & Technology & Technology & $\begin{array}{l}\text { Uptake } \\
\text { rate }(\%)\end{array}$ \\
\hline Finland & $5,540,720$ & 83.2 & 44.91 & Koronavilkku & Yes & Bluetooth & Google/Apple & 45 \\
\hline Denmark & $5,792,202$ & 164.0 & 45.37 & Smittestopp & Yes & Bluetooth & Google/Apple & - $^{\mathrm{c}}$ \\
\hline Switzerland & $8,654,622$ & 643.8 & 46.30 & SwissCovid & Yes & Bluetooth & $\begin{array}{l}\text { Google/Apple } \\
\text { DP3T }^{\mathrm{d}}\end{array}$ & 21 \\
\hline Estonia & $1,326,535$ & 116.1 & 48.15 & Estonia's App & No & Bluetooth & Google/Apple & - \\
\hline Norway & $5,421,241$ & 72.5 & 52.78 & Smittestopp & Yes & $\begin{array}{l}\text { Bluetooth } \\
\text { and location }\end{array}$ & Other & - \\
\hline $\begin{array}{l}\text { United King- } \\
\text { dom }\end{array}$ & $67,886,011$ & 948.7 & 54.17 & NHSCovid19 & Yes & Bluetooth & Google/Apple & - \\
\hline Netherlands & $17,134,872$ & 587.9 & 56.48 & Coronamelder & Yes & Bluetooth & Google/Apple & - \\
\hline Bulgaria & $6,948,445$ & 840.2 & 57.41 & ViruSafe & Yes & Location & Other & - \\
\hline Belgium & $11,589,623$ & 1557.8 & 60.19 & Coronoalert & Yes & Bluetooth & $\begin{array}{l}\text { Google/Apple } \\
\text { DP3T }\end{array}$ & - \\
\hline Germany & $83,783,942$ & 268.2 & 67.59 & Corona-Warn-App & Yes & Bluetooth & Google/Apple & 19 \\
\hline Cyprus & $1,207,359$ & 67.9 & 69.44 & CovTracer & Yes & Location & Other & - \\
\hline Poland & $37,846,611$ & 615.9 & 71.30 & ProteGO & Yes & Bluetooth & Google/Apple & - \\
\hline Spain & $46,754,778$ & 1026.9 & 71.30 & RadarCOVID & Yes & Bluetooth & $\begin{array}{l}\text { Google/Apple } \\
\text { DP3T }\end{array}$ & - \\
\hline Ireland & $4,937,786$ & 430.6 & 72.22 & Covid Tracker & Yes & Bluetooth & Google/Apple & 24 \\
\hline Hungary & $9,660,351$ & 749.1 & 72.22 & VirusRadar & Yes & Bluetooth & Other & - \\
\hline France & $65,273,511$ & 887.2 & 75.00 & TousAntiCovid & Yes & Bluetooth & Other & 19 \\
\hline Portugal & $10,196,709$ & 554.0 & 77.78 & Stay away Covid & Yes & Bluetooth & $\begin{array}{l}\text { Google/Apple } \\
\text { DP3T }\end{array}$ & - \\
\hline Italy & $60,461,826$ & 1075.2 & 79.63 & Immuni & No & Bluetooth & Google/Apple & 13 \\
\hline Austria & $9,006,398$ & 500.8 & $82.41^{\mathrm{e}}$ & Stopp Corona & Yes & Bluetooth & Google/Apple & - \\
\hline
\end{tabular}

${ }^{\mathrm{a}}$ The Government Stringency Index is a composite measure based on 9 response indicators, including school closures, workplace closures, and travel bans, rescaled to a value ranging from 0 to $100(100=$ strictest $)$.

${ }^{\mathrm{b}}$ Data were extracted several days after their acquisition.

${ }^{\mathrm{c}}$ Not available.

${ }^{\mathrm{d}}$ DP3T: decentralized privacy-preserving proximity tracing.

${ }^{\mathrm{e}}$ Data as of December 8, 2020.

\section{Discussion}

There are several challenges in motivating populations to download DCT apps, even though it is a promising tool. Between European policies of isolation, which are either strict and instituted by national regulations with severe fines or based on incentives, the CCL recommends an intermediate position with national guidelines accompanied by strong incentive supports, ensuring good adherence from the population and avoiding the weakening of the "testing and contact tracing" facets of the national strategy. However, apps will not by themselves resolve the problem of isolation nonadherence, particularly among persons who are outside the health care system. The CCL recommends adaptations of the informational process for these persons. With regard to those for whom pragmatic isolation is difficult, because of home overcrowding, family composition, or work needs, the CCL recommends a prosocial approach with community officers who ensure that sufficient supplies (eg, essentials such as food, medication, and childcare resources) are provided [18].

To conclude, the CCL calls for promoting empowerment of the population with digital tools, improving public health culture for decision-makers dealing with health determinants, taking social considerations into account, and incorporating community participation [19]. 


\section{Conflicts of Interest}

All authors are members of the French COVID-19 Control and Society Connection Council (CCL).

\section{Multimedia Appendix 1}

Description of the French COVID-19 Control and Society Connection Council.

[DOCX File, 23 KB-Multimedia Appendix 1]

\section{References}

1. Pachetti M, Marini B, Giudici F, Benedetti F, Angeletti S, Ciccozzi M, et al. Impact of lockdown on Covid-19 case fatality rate and viral mutations spread in 7 countries in Europe and North America. J Transl Med 2020 Sep 02;18(1):338 [FREE Full text] [doi: 10.1186/s12967-020-02501-x] [Medline: $\underline{\text { 32878627] }}$

2. Whitelaw S, Mamas MA, Topol E, Van Spall HGC. Applications of digital technology in COVID-19 pandemic planning and response. The Lancet Digital Health 2020 Aug;2(8):e435-e440 [FREE Full text] [doi: 10.1016/S2589-7500(20)30142-4]

3. Murray CJL, Alamro NMS, Hwang H, Lee U. Digital public health and COVID-19. The Lancet Public Health 2020 Sep;5(9):e469-e470. [doi: 10.1016/s2468-2667(20)30187-0]

4. Decree no 2020-572 of May 15, 2020 relating to the Covid-19 Control and Liaison Committee. Legifrance. 2020 May 17. URL: https://www.legifrance.gouv.fr/loda/id/JORFTEXT000041884917/2020-12-16/ [accessed 2021-08-04]

5. Bengio Y, Janda R, Yu YW, Ippolito D, Jarvie M, Pilat D, et al. The need for privacy with public digital contact tracing during the COVID-19 pandemic. Lancet Digit Health 2020 Jul;2(7):e342-e344 [FREE Full text] [doi:

10.1016/S2589-7500(20)30133-3] [Medline: 32835192]

6. Morley J, Cowls J, Taddeo M, Floridi L. Ethical guidelines for COVID-19 tracing apps. Nature 2020 Jun;582(7810):29-31. [doi: 10.1038/d41586-020-01578-0] [Medline: 32467596]

7. Jonker M, de Bekker-Grob E, Veldwijk J, Goossens L, Bour S, Rutten-Van Mölken M. COVID-19 contact tracing apps: predicted uptake in the Netherlands based on a discrete choice experiment. JMIR Mhealth Uhealth 2020 Oct 09;8(10):e20741 [FREE Full text] [doi: 10.2196/20741] [Medline: 32795998]

8. Blasimme A, Vayena E. What's next for COVID-19 apps? governance and oversight. Science 2020 Nov 13;370(6518):760-762. [doi: 10.1126/science.abd9006] [Medline: 33184192]

9. Heffner J, Vives M, FeldmanHall O. Emotional responses to prosocial messages increase willingness to self-isolate during the COVID-19 pandemic. Pers Individ Dif 2021 Feb 15;170:110420 [FREE Full text] [doi: 10.1016/j.paid.2020.110420] [Medline: 33082614 ]

10. Walrave M, Waeterloos C, Ponnet K. Adoption of a contact tracing app for containing COVID-19: a health belief model approach. JMIR Public Health Surveill 2020 Sep 01;6(3):e20572 [FREE Full text] [doi: 10.2196/20572] [Medline: 32755882]

11. Watts G. COVID-19 and the digital divide in the UK. Lancet Digit Health 2020 Aug;2(8):e395-e396 [FREE Full text] [doi: 10.1016/S2589-7500(20)30169-2] [Medline: $\underline{32835198]}$

12. Thomas R, Michaleff ZA, Greenwood H, Abukmail E, Glasziou P. Concerns and misconceptions about the Australian government's COVIDSafe app: cross-sectional survey study. JMIR Public Health Surveill 2020 Nov 04;6(4):e23081 [FREE Full text] [doi: 10.2196/23081] [Medline: $\underline{33048826}$ ]

13. Conclusion of the Assises Citoyennes du Numérique en Santé: the French are ready for digital health if it is built for and with them. DSIH. 2020 Nov 20. URL: https://www.dsih.fr/article/3986/ conclusion-des-assises-citoyennes-du-numerique-en-sante-les-francais-sont-prets-pour-le-numerique-en-sante-s-il-est-construit-pour-et-avec-eux. html [accessed 2020-12-08]

14. Beauchamps M. First results of the Capacity survey. Marsouin. 2017 Mar 23. URL: https://www.marsouin.org/article953. html [accessed 2021-08-04]

15. Banskota S, Healy M, Goldberg EM. 15 smartphone apps for older adults to use while in isolation during the COVID-19 pandemic. West J Emerg Med 2020 Apr 14;21(3):514-525 [FREE Full text] [doi: 10.5811/westjem.2020.4.47372] [Medline: 32302279]

16. Atlani-Duault L, Lina B, Malvy D, Yazdanpanah Y, Chauvin F, Delfraissy J. COVID-19: France grapples with the pragmatics of isolation. The Lancet Public Health 2020 Nov;5(11):e573-e574. [doi: 10.1016/s2468-2667(20)30235-8]

17. Hale T, Angrist N, Goldszmidt R, Kira B, Petherick A, Phillips T, et al. A global panel database of pandemic policies (Oxford COVID-19 Government Response Tracker). Nat Hum Behav 2021 Apr 08;5(4):529-538. [doi: 10.1038/s41562-021-01079-8] [Medline: 33686204]

18. Webster RK, Brooks SK, Smith LE, Woodland L, Wessely S, Rubin GJ. How to improve adherence with quarantine: rapid review of the evidence. Public Health 2020 May;182:163-169 [FREE Full text] [doi: 10.1016/j.puhe.2020.03.007] [Medline: 32334182]

19. Marston C, Renedo A, Miles S. Community participation is crucial in a pandemic. The Lancet 2020 May;395(10238):1676-1678. [doi: 10.1016/s0140-6736(20)31054-0] 


\section{Abbreviations \\ CCL: COVID-19 Control and Society Connection Council \\ DCT: digital contact tracing \\ RT-PCR: reverse-transcription polymerase chain reaction}

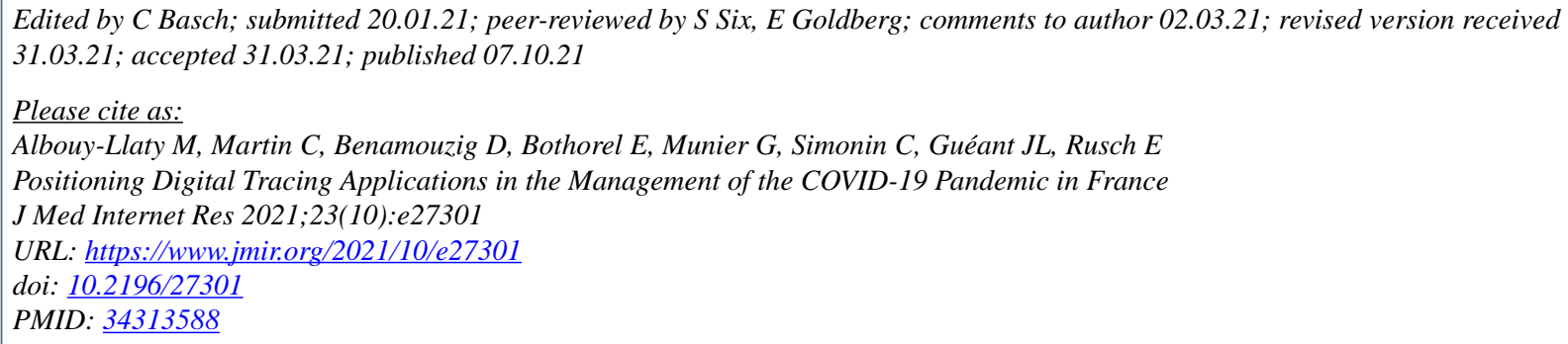

CMarion Albouy-Llaty, Caroline Martin, Daniel Benamouzig, Eric Bothorel, Gilles Munier, Catherine Simonin, Jean-Louis Guéant, Emmanuel Rusch. Originally published in the Journal of Medical Internet Research (https://www.jmir.org), 07.10.2021. This is an open-access article distributed under the terms of the Creative Commons Attribution License (https://creativecommons.org/licenses/by/4.0/), which permits unrestricted use, distribution, and reproduction in any medium, provided the original work, first published in the Journal of Medical Internet Research, is properly cited. The complete bibliographic information, a link to the original publication on https://www.jmir.org/, as well as this copyright and license information must be included. 